\title{
PENGARUH GREEN MARKETING MIX TERHADAP VALUE PERCEPTION DAN MINAT BELI KONSUMEN THE BODY SHOP DI KOTA MATARAM
}

\author{
Maya Triana ${ }^{1}$, Sulhaini ${ }^{2}$ \\ 1Program Studi Magister Manajemen Fakultas Ekonomi dan Bisnis Unram, \\ mayatriana2019@gmail.com \\ 2Fakultas Ekonomi dan Bisnis, Universitas Mataram, niniys@yahoo.co.uk
}

\begin{abstract}
ARTICLE INFO
Keywords :

Green Marketing Mix, Value Perception, Intention To Buy, Cosmetic Product, The Body Shop.
\end{abstract}

\section{How to cite :}

Triana, M., Sulhaini (2019). Pengaruh Green Marketing Mix Terhadap Value Perception dan Minat Beli Konsumen The Body Shop di Kota Mataram. JMM UNRAM, 8(2),115-129

DOI :

http://dx.doi.org/10.29303/jmm.v8i2.429

$\begin{array}{ll}\text { Dikumpulkan } & : 13 \text { Mei } 2019 \\ \text { Direvisi } & : 20 \text { Mei } 2019 \\ \text { Dipublikasi } & : 21 \text { Mei } 2019\end{array}$

\begin{abstract}
This research examined the effect of Green Marketing Mix, Value Perception and Intention To Buy cosmetic product of The Body Shop in Mataram City. This research is specifically aimed at determining the significance of the effect of Green Marketing Mix on Value Perception and Intention To Buy on cosmetic product at The Body Shop in Mataram City. The population of this study was customer of cosmetic product of The Body Shop in Mataram City, contain 100 respondents using purposive sampling method. The instrument in this study tested using Confirmatory Factor Analysis, while the reliability test using Cronbach Alpha. This research using Structural Equation Modelling employing SmartPLS program to test the hypothesis. The research results showed that Green Marketing Mix significantly and positively affect the Value Perception, Green Marketing Mix significantly and positively affect the Intention To Buy, Value Perception significantly and positively affect the Intention To Buy. Green Marketing Mix significantly and positively affect the Intention To Buy throught Value Perception. The Body Shop needs to make the subject of promotion more supportive of environmental exceptions in real terms, for example the program for saving rare animals, holding river cleaning activities or tree planting programs that involve customers directly.
\end{abstract}

Penelitian ini menguji pengaruh antara Green Marketing Mix, Value Perception dan Minat Beli pada produk kosmetik The Body Shop di Kota Mataram. Secara spesifik tujuan dari penelitian ini adalah untuk mengetahui signifikansi pengaruh Green Marketing Mix terhadap Value Perception dan Minat Beli pada produk kosmetik The Body Shop di Kota Mataram. Sampel yang digunakan adalah pelanggan pengguna produk kosmetik The Body Shop di Kota Mataram dan diambil sebanyak 100 responden dengan 


\section{NATIONALLY ACCREDITED J OURNAL - DECREE NO, 21/E/KPT/2018}

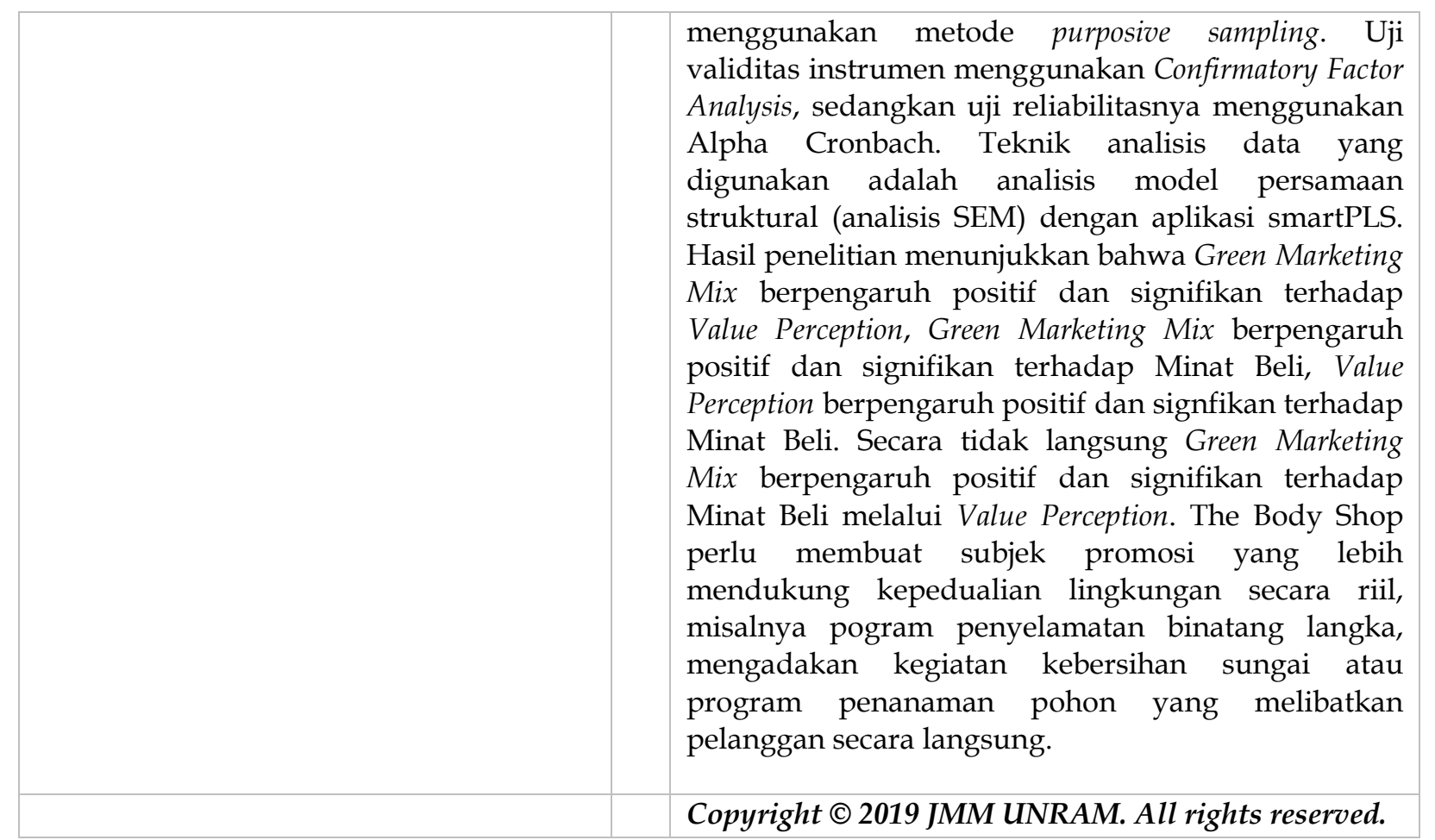

\section{PENDAHULUAN}

Istilah green marketing muncul kepermukaan sebagai reaksi dari para marketer untuk peduli lingkungan. Pendekatan pemasaran hijau (green marketing approach) pada area produk diyakini dapat meningkatkan integrasi dari isu lingkungan pada seluruh aspek dari aktivitas perusahaan, mulai dari formulasi strategi, perencanaan, penyusunan, sampai produksi dan penyaluran atau distribusi dengan pelanggan (Pride \& Ferrell, 1993; dalam Manongko, 2011). Penelitian mengenai pengaruh persepsi green marketing mix terhadap minat beli konsumen dilakukan oleh Kong et al, (2014) yang menunjukkan bahwa green marketing mix memiliki pengaruh positif signifikan terhadap minat beli. Yani \& Astuti (2016) dalam penelitiannya juga menunjukkan bahwa variabel green marketing mix berpengaruh signifikan terhadap keputusan pembelian melalui minat beli. Temuan dalam penelitian tersebut semakin menguatkan bahwa minat beli konsumen dapat terbentuk dengan baik karena adanya pengaruh dari green marketing mix. Dari hasil penelitian tersebut dapat dijelaskan bahwa setiap kali terjadi peningkatan green marketing mix akan diikuti oleh peningkatan minat beli konsumen. Walaupun banyak penelitian terdahulu yang telah dilakukan untuk mengetahui pengaruh antara green marketing mix terhadap minat beli, tetapi masih terdapat perbedaan hasil penelitian. Seperti halnya dengan temuan Rehman \& Khyzer (2013) yang menunjukkan bahwa green marketing mix tidak signifikan dalam mempengaruhi minat beli pada mahasiswa di Pakistan. Adanya perbedaan hasil riset ini perlu diteliti lebih lanjut sehingga bisa dijadikan dasar manajemen untuk pengambilan keputusan lebih lanjut. Green marketing mix menjadi tidak signifikan terhadap minat beli dimungkinkan karena ada variabel lain yang memiliki peran dominan.

Variabel lain yang sangat dominan dalam mempengaruhi minat beli konsumen adalah value perception atau persepsi nilai (Pratama, 2014; dan Rosiana, 2017). Value perception menurut Aaker (1997) dapat didefinisikan sebagai persepsi pelanggan terhadap keseluruhan kualitas atau keunggulan suatu produk atau jasa layanan berkaitan dengan apa yang diharapkan oleh pelanggan. Value perception akan membentuk persepsi kualitas 


\section{NATIONALLY ACCREDITED J OURNAL - DECREE NO, 21/E/KPT/2018}

dari suatu produk dimata pelanggan. Value perception dari produk hijau sendiri dianggap aman oleh konsumen karena dengan label tersebut produsen seharusnya menyediakan produk yang berbahan aman, sehingga hal ini diyakini akan mempengaruhi minat beli terhadap produk hijau. Banyak penelitian telah dilakukan yang menunjukkan terdapat pengaruh positif yang signifikan antara value perception dengan minat beli (Pratama, 2014; dan Rosiana, 2017). Namun, berdasarkan penelitian oleh Amalia, Lestari \& Kardinal (2012) diketahui bahwa value perception tidak berpengaruh signifikan terhadap terhadap minat beli. Hal ini menegaskan bahwa penelitian sebelumnya tentang pengaruh antara value perception terhadap minat beli konsumen belum menunjukkan temuan yang konsisten.

Beberapa hasil penelitian seperti penelitian yang telah dilakukan oleh Saraswaty \& Suprapti (2015) menunjukkan hasil bahwa persepsi nilai dapat memediasi pengaruh pemasaran hijau terhadap niat pembelian produk hijau. Hasil penelitian yang dilakukan oleh Suprapto \& Efendi (2017) menunjukkan terdapat pengaruh mediasi penuh pada persepsi nilai tentang hubungan antara perilaku pembelian hijau dan kepedulian lingkungan. Selanjutnya hasil penelitian Aprilisya, Yasa \& Giantari (2017) menyebutkan bahwa persepsi nilai secara signifikan memediasi pengaruh antara pemasaran hijau terhadap niat beli produk ramah lingkungan. Hasil ini berarti bahwa melalui adanya persepsi nilai yang positif dari konsumen terhadap produk ramah lingkungan maka mengimplikasi bentuk pemasaran yang dilakukan oleh perusahaan dengan pemasaran yang berbasis ramah lingkungan atau dengan istilah pemasaran hijau yang berhasil menarik niat konsumen untuk melakukan pembelian produk ramah lingkungan tersebut. Stevanie (2015) dalam penelitiannya juga menemukan bahwa variabel value perception dipengaruhi oleh green marketing mix. Hal ini ditegaskan lagi oleh Dhewi, Putra, Soeharto \& Wahyudi (2018) bahwa value perception atau nilai yang dipersepsikan pada produk ramah lingkungan juga berkorelasi positif dengan green marketing mix. Dengan adanya temuan tersebut menjadikan variabel dalam penelitian ini saling berkorelasi sehingga memunculkan model penelitian terbaru yang disusun berdasarkan kombinasi temuan dalam penelitian terdahulu. Namun demikian masih terdapat perbedaan hasil penelitian yang dilakukan oleh peneliti terdahulu, sehingga perlu dilakukan penelitian lanjutan dalam waktu dan ruang lingkup yang berbeda dengan mengkombinasikan model penelitian terbaru, dalam konteks ini yakni, penelitian terhadap produk ramah lingkungan. Salah satu produk dari strategi green marketing yang sulit dipilih oleh konsumen adalah produk kecantikan. The Body Shop muncul di tengah kesadaran calon konsumen akan produk ramah lingkungan. The Body Shop adalah perusahaan produsen kosmetik atau produk kecantikan yang terbuat dari bahan alami yang ramah lingkungan. Perbedaan The Body Shop dengan produk kecantikan lain adalah strategi green marketing yang diterapkan. Green marketing yang diterapkan perusahaan diharapkan akan membentuk sebuah dorongan seperti value perception terhadap suatu produk. Hal ini selanjutnya menjadi panutan dalam mengakomodasi perilaku konsumen, sehingga mempengaruhi minat pembelian. Perusahaan yang menerapkan konsep green marketing tentunya akan lebih banyak dicari, disukai dan diminati oleh konsumen, khususnya konsumen yang selektif dalam pembelian produk ramah lingkungan.

\section{KAJIAN PUSTAKA}

\subsection{Hubungan Green Marketing Mix dengan Value Perception}

Nilai yang dipersepsikan ialah keseluruhan penilaian dari utilitas produk berdasarkan persepsi yang diberikan dan persepsi yang diterima (Kotler \& Keller, 2012). Nilai yang diterima konsumen dengan mengangkat tema penyelamatan lingkungan akan 


\section{NATIONALLY ACCREDITED J OURNAL - DECREE NO, 21/E/KPT/2018}

mempengaruhi keputusan konsumen untuk membeli produk yang menerapkan strategi green marketing mix dalam proses pembuatan produk (Kotler \& Keller, 2012). Pujari (2003) menyebutkan bahwa green marketing mix yang dilakukan oleh perusahaan memiliki dampak positif bagi perusahaan, antara lain: meningkatnya penjualan, memperbaiki umpan balik dari pelanggan, lebih dekat kepada pelanggan, mempertinggi kemampuan bersaing, memperbaiki citra perusahaan. Dampak baik untuk perusahaan selain mendapatkan penjualan yang meningkat, konsumen juga akan membantu perusahaan tersebut untuk ikut menggalakkan penyelamatan lingkungan. Maka citra perusahaan akan meningkat dengan kondisi seperti ini. Green marketing mix secara signifikan telah terbukti dalam mempengaruhi nilai yang dipersepsikan (value perception) sebagaimana dikemukakan oleh Stevanie (2015). Hal ini ditegaskan oleh penelitian Dhewi et al, (2018) yang menyatakan value perception pada produk ramah lingkungan berkorelasi positif dengan green marketing mix. Maka hipotesis pertama yang diajukan dalam penelitian adalah sebagai berikut:

$\mathrm{H}_{1}$ : green marketing mix berpengaruh positif dan signifikan terhadap value perception pada pelanggan The Body Shop di Kota Mataram.

\subsection{Hubungan Green Marketing Mix dengan Minat Beli}

Dalam berbagai literatur dikemukakan bahwa seiring terjadinya globalisasi yang berdampak buruk pada lingkungan, masyarakat mengalami pergeseran pola pikir menuju pola hidup yang ramah lingkungan atau biasa disebut green consummer (Retnawati, 2011). Perusahaan menangkap hal tersebut sebagai sebuah peluang baru dengan menyedikan produk yang ramah lingkungan atau green product. Kong et al, (2014) dalam penelitiannya menunjukkan bahwa green marketing mix memiliki pengaruh positif signifikan terhadap minat beli. Senada dengan Yani \& Astuti (2016) yang juga menunjukkan bahwa variabel green marketing mix berpengaruh signifikan terhadap keputusan pembelian melalui minat beli, hal ini menegaskan bahwa model fit dalam penelitian tersebut menandakan adanya hubungan yang linier pada variabel green marketing mix dengan minat beli. Dengan adanya fenomena green consumer disertai dengan tersedianya green product diyakini akan meningkatkan minat beli masyarakat sebagai konsumen untuk membeli green product. Dari uraian tersebut maka dapat diajukan hipotesis sebagai berikut:

$\mathrm{H}_{2}$ : green marketing mix berpengaruh positif dan signifikan terhadap minat beli pada pelanggan The Body Shop di Kota Mataram.

\subsection{Hubungan Value Perception dengan Minat Beli}

Beberapa studi yang dilakukan oleh Chan (1999) dan Ottman (1995) menemukan bahwa pada konsumen yang berwawasan lingkungan cenderung melakukan aktifitas terkait kepedulian lingkungan yang kuat, dan konsumen lebih memilih produk-produk yang ramah lingkungan dibandingkan produk yang lain. Menurut Chan (2001) bahwa orientasi seseorang terhadap alam, kolektivitas, pengaruh ekologi, dan pengetahuan tentang ekologi lingkungan berpengaruh terhadap sikap untuk melakukan minat pembelian produk ramah lingkungan. Begitu pula dengan adanya green product yang disediakan diyakini akan meningkatkan minat beli konsumen pada produk ramah lingkungan. Pratama (2014); dan Rosiana (2017) dalam penelitiannya menunjukkan terdapat pengaruh positif yang signifikan antara value perception terhadap minat beli. Hal ini dipertegas oleh Cahyani \& Wardana (2017) yang mengemukakan bahwa kepercayaan dapat memperkuat persepsi positif konsumen terhadap suatu produk sehingga memunculkan niat untuk melakukan pembelian ulang. Dari uraian tersebut maka dapat diajukan hipotesis sebagai berikut:

$\mathrm{H}_{3}$ : value perception berpengaruh positif dan signifikan terhadap minat beli pada pelanggan The Body Shop di Kota Mataram. 


\section{NATIONALLY ACCREDITED J OURNAL - DECREE NO. 21/E/KPT/2018}

\subsection{Kerangka Konsep}

Berdasarkan kajian pustaka di atas, dapat dijelaskan konseptual berikut ini:

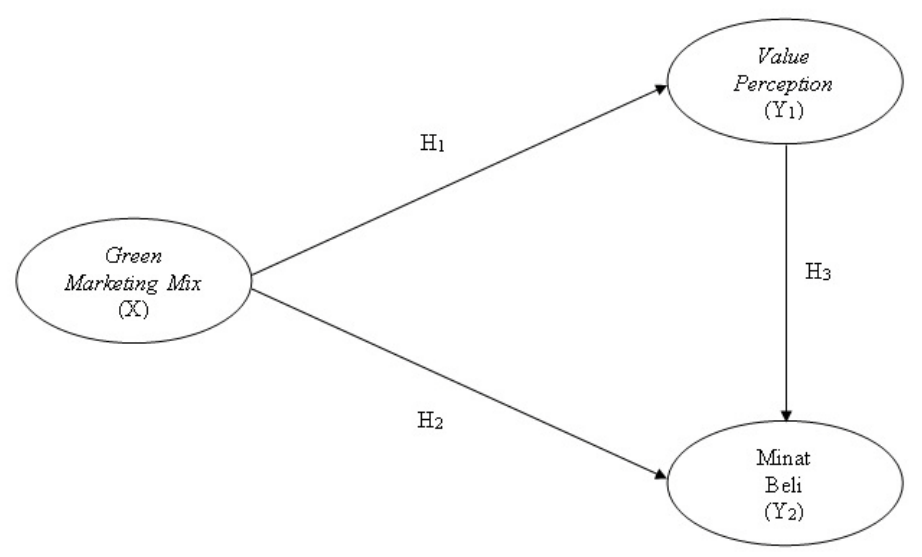

Sumber: Rangkuman dari Kajian Pustaka

\section{METODE PENELITIAN}

\subsection{Jenis Penelitian}

Studi ini merupakan penelitian dengan pendekatan kausalitas. Penelitian ini mencari pengaruh sebab-akibat antara green marketing mix (produk, harga, tempat, promosi) terhadap value perception dan minat beli. Populasi pada penelitian ini adalah seluruh pelanggan yang mengetahui produk The Body Shop di Kota Mataram. Jumlah sampel yang ditetapkan dalam penelitian ini sebanyak 100 responden. Teknik pengambilan sampel dalam penelitian ini adalah Non Probability Sampling yaitu purposive sampling. Dalam penelitian ini pemilihan sampel berdasarkan pada kriteria sebagai berikut: 1) Pelanggan yang datang berkunjung ke outlet The Body Shop di Kota Mataram; 2) Pelanggan telah menggunakan produk The Body Shop lebih dari 2 tahun; 3) Pelanggan The Body Shop yang berusia 18 tahun ke atas.

Kuesioner dalam penelitian ini dibagikan kepada 100 respoden dalam dua tahap. Tahap pertama peneliti menyebarkan sebanyak 30 kuesioner kepada responden. Selanjutnya dilakukan uji kualitas instrumen untuk mengetahui validitas dan reliabilitas kuesioner. Berdasarkan hasil analisis korelasi Product Moment Pearson diketahui bahwa setiap indikator variabel kuisioner penelitian secara keseluruhan dinyatakan valid, hal ini ditunjukkan oleh nilai $r$ hitung yang lebih besar dari nilai $r$ kritis. Berikutnya hasil alfa Cronbach setiap variabel bernilai di atas 0,600 yang menyatakan kuesioner reliabel, sehingga kuesioner dalam penelitian ini layak digunakan sebagai instrumen pengumpulan data. Selanjutnya pada tahap kedua peneliti menyebarkan 70 kuesioner kepada responden, yang kesemuanya diikutsertakan pada proses analisis data.

\subsection{Gambaran Umum Responden}

Berdasarkan penelitian yang dilakukan dengan memberikan kuesioner atau daftar pernyataan kepada 100 orang responden pelanggan The Body Shop di Kota Mataram, diketahui sebagian besar pelanggan berjenis kelamin perempuan (92 persen). Mayoritas pelanggan berusia antara 21 tahun sampai 40 tahun. Pelanggan The Body Shop di Kota Mataram mempunyai latar belakang pendidikan S1 sebanyak 53 persen. Profesi pelanggan didominasi oleh karyawan (pegawai yang bekerja pada instansi swasta) sebesar 36 persen. Tingkat penghasilan pelanggan antara Rp2.000.001 - Rp5.000.000 sebanyak 66 persen. 


\section{NATIONALLY ACCREDITED J OURNAL - DECREE NO, 21/E/KPT/2018}

Diketahui pula lama menggunakan produk The Body Shop didominasi oleh pelanggan yang menggunakan produk antara 2 sampai 5 tahun sebanyak 63 persen. Pelanggan The Body Shop di Kota Mataram rata-rata melakukan pembelian produk setiap sebulan sekali yaitu sebanyak 39 persen.

\subsection{Definisi Operasional Variabel}

1) Variabel Laten Eksogen: Green Marketing Mix

Green marketing mix merupakan seluruh aktivitas pada produk The Body Shop yang didesain untuk menghasilkan dan memfasilitasi semua perubahan yang diharapkan dapat memuaskan kebutuhan dan keinginan pelanggannya, dengan dampak minimal pada perusakan lingkungan alam. Skala pengukuran yang digunakan adalah skala Likert. Adapun dimensi-dimensi atau variabel manifes dari green marketing mix sebagai berikut: Green Product, Green Price, Green Place, dan Green Promotion.

2) Variabel Laten Endogen Antara: Value Perception

Value perception atau persepsi nilai adalah nilai yang dipikirkan pelanggan produk The Body Shop yang merupakan selisih antara evaluasi calon pelanggan atas semua manfaat serta semua biaya tawaran tertentu dan alternatif-alternatif lain yang dipikirkan. Persepsi responden terkait value perception dinyatakan dengan skala Likert. Indikator-indikator pengukurnya adalah: Nilai Fungsional, Nilai Emosional dan Nilai Ekspresi.

3) Variabel Laten Endogen Tergantung: Minat Beli

Minat beli adalah adanya persepsi yang timbul dari responden setelah menerima stimulus dari produk The Body Shop yang dilihatnya. Dari stimulus tersebut timbul rasa keinginan untuk mencoba atau mempergunakan produk tersebut, sehingga dari keinginan tersebut memunculkan minat beli dari diri konsumen. Persepsi responden terkait minat beli dinyatakan dengan skala Likert. Tinggi rendahnya minat beli konsumen dapat diukur melalui indikator yaitu: Minat Transaksional, Minat Referensial, Minat Preferensial, dan Minat Eksploratif.

\subsection{Alat Analisis}

Dalam penelitian ini, analisis data dengan statistika digunakan SEM-PLS bantuan software Smart PLS. Teknik pengolahan data dengan menggunakan metode SEM berbasis PLS memerlukan tahapan penilaian Fit Model dari sebuah model penelitian (Ghozali, 2015). Terdapat 3 kriteria dalam penggunaan SmartPLS untuk menilai Outer Model yaitu Convergent Validity, Discriminant Validity, dan Composite Reliability. Convergent Validity dari model pengukuran dengan refleksif indikator dinilai berdasarkan korelasi antara item score atau component score yang diestimasi dengan Software SmartPLS. Ukuran refleksif individual dikatakan tinggi jika berkorelasi lebih dari 0,70 dengan variabel yang diukur. Namun menurut Chin (1998) dalam Ghozali (2015) untuk penelitian tahap awal skala pengukuran nilai loading 0,50 sampai 0,60 dianggap cukup memadai. Dalam penelitian ini digunakan batas loading factor sebesar 0,60. Hasil pengolahan dengan menggunakan PLS dapat dilihat pada Tabel 1. Nilai outer model atau korelasi antara indikator dengan variabel yang telah memenuhi convergent validity karena memiliki nilai loading factor di atas 0,60 dianalisis lebih lanjut, sedangkan yang tidak memenuhi kriteria tidak diikutsertakan dalam analisis selanjutnya. 


\section{NATIONALLY ACCREDITED J OURNAL - DECREE NO. 21/E/KPT/2018}

Tabel 1. Outer Loadings (Measurement Model)

\begin{tabular}{|c|c|c|c|}
\hline No. & Variabel & Indikator & Outer Loading \\
\hline \multirow{14}{*}{1} & \multirow{14}{*}{$\begin{array}{l}\text { Green Marketing Mix } \\
(\mathrm{X})\end{array}$} & Ramah lingkungan & 0,637 \\
\hline & & $\begin{array}{c}\text { Efisiensi sumber } \\
\text { daya }\end{array}$ & 0,652 \\
\hline & & Standarisasi & 0,637 \\
\hline & & Harga terjangkau & 0,618 \\
\hline & & Sebanding & 0,674 \\
\hline & & kualitasnya & \\
\hline & & Hadiah pembelian & 0,680 \\
\hline & & Jarak outlet & 0,720 \\
\hline & & Banyak outlet & 0,750 \\
\hline & & $\begin{array}{l}\text { Kelengkapan di } \\
\text { outlet }\end{array}$ & 0,856 \\
\hline & & Kualifikasi & 0,702 \\
\hline & & lingkungan & \\
\hline & & Aplikasi lingkungan & 0,771 \\
\hline & & Perbandingan & 0,694 \\
\hline \multirow{3}{*}{2} & \multirow{3}{*}{$\begin{array}{c}\text { Value Perception } \\
\qquad\left(\mathrm{Y}_{1}\right)\end{array}$} & Nilai fugsional & 0,780 \\
\hline & & Nilai emosional & 0,790 \\
\hline & & Nilai ekspresi diri & 0,823 \\
\hline \multirow{4}{*}{3} & \multirow{4}{*}{$\begin{array}{l}\text { Minat Beli } \\
\left(\mathrm{Y}_{2}\right)\end{array}$} & Minat transaksional & 0,855 \\
\hline & & Minat referensial & 0,870 \\
\hline & & Minat preferensial & 0,893 \\
\hline & & Minat eksploratif & 0,913 \\
\hline
\end{tabular}

Tabel 1 menunjukkan bahwa seluruh indikator Green Marketing Mix memiliki nilai outer loading lebih besar dari 0,60. Indikator kelengkapan produk di setiap outlet $\left(\mathrm{X}_{1.09}\right)$ merupakan ukuran terkuat dari variabel Green Marketing Mix karena memiliki nilai outer loading paling besar $(0,856)$. Dapat dinyatakan bahwa 12 indikator Green Marketing Mix merupakan indikator yang valid sebagai pengukur variabel Minat Beli. Untuk variabel Value Perception membuktikan bahwa terdapat tiga indikator yang memiliki outer loading lebih besar dari 0,60. Indiktor nilai ekspresi $\left(\mathrm{Y}_{1.03}\right)$ merupakan ukuran terkuat dari variabel Value Perception karena memiliki nilai outer loading paling besar $(0,823)$. Sehingga dapat dinyatakan bahwa ketiga indikator Value Perception merupakan indikator yang valid sebagai pengukur variabel Minat Beli. Selanjutnya dengan memperhatikan nilai rata-rata pada variabel Minat Beli, terdapat empat indikator yang memiliki nilai outer loading lebih besar dari 0,60. Hasil ini menujukkan bahwa minat transaksional, referensial, preferensial, dan eksploratif merupakan indikator terkuat dalam mengukur Minat Beli. Hasil pengujian discriminant validity ditampilkan pada Tabel 2 :

Tabel 2. Discriminant Validity

\begin{tabular}{cccccc}
\hline \multicolumn{3}{c}{ Average Variance Extracted } & \multicolumn{3}{c}{ Korelasi } \\
\hline & AVE & $\begin{array}{c}\text { Akar } \\
\text { AVE }\end{array}$ & $\begin{array}{c}\text { Green } \\
\text { Marketing } \\
\text { Mix }(\mathbf{X})\end{array}$ & $\begin{array}{c}\text { Value } \\
\text { Perception } \\
\left(\mathrm{Y}_{1}\right)\end{array}$ & $\begin{array}{c}\text { Minat Beli } \\
\left(\mathrm{Y}_{2}\right)\end{array}$ \\
\hline Green Marketing Mix $(\mathrm{X})$ & 0,493 & 0,702 & 1,000 & & \\
Value Perception $\left(\mathrm{Y}_{1}\right)$ & 0,636 & 0,798 & 0,713 & 1,000 & \\
$\quad$ Minat Beli $\left(\mathrm{Y}_{2}\right)$ & 0,779 & 0,883 & 0,742 & 0,664 & 1,000 \\
\hline
\end{tabular}

Discriminant validity dilakukan untuk memastikan bahwa setiap konsep dari masingmasing variabel laten berbeda dengan variabel lainnya. Model dikatakan mempunyai 


\section{NATIONALLY ACCREDITED J OURNAL - DECREE NO. 21/E/KPT/2018}

discriminant validity yang baik jika setiap nilai loading indikator dari sebuah variabel laten memiliki nilai loading yang lebih besar dibanding nilai loading jika dikorelasikan dengan variabel laten lainnya.

Pada Tabel 2 Value Perception dan Minat Beli memiliki nilai Average Variance Extracted (AVE) di atas 0,50, sedangkan Green Marketing Mix masih berada pada batas toleransi mendekati nilai 0,50 yaitu 0,493. Artinya, variabel laten Green Marketing Mix dapat menjelaskan rata-rata hampir dari setengah varian dari indikator-indikatornya. Discriminant validity dari model reflektif dievaluasi melalui cross loading, kemudian dibandingkan nilai AVE dengan kuadrat dari nilai korelasi antar konstruk (atau membandingkan akar kuadrat AVE dngan korelasi antar konstruknya). Ukuran cross loading adalah membandingkan korelasi indikator dengan konstruknya dan konstruk dari blok lainnya. Bila korelasi antara indikator dengan konstruknya lebih tinggi dari korelasi dengan konstruk blok lainnya, hal ini menunjukkan konstruk tersebut memprediksi ukuran pada blok mereka dengan lebih baik dari blok lainnya. Ukuran discriminant validity lainnya adalah bahwa nilai akar AVE harus lebih tinggi daripada korelasi antara konstruk dengan konstruk lainnya atau nilai AVE lebih tinggi dari kuadrat korelasi antara konstruk. Dengan demikian semua variabel memiliki nilai akar AVE lebih tinggi dari koefisien korelasi antar satu variabel dengan variabel lainnya sehingga dapat dikatakan data memiliki discriminant validity yang baik.

Kriteria validity dan reliabilitas juga dilihat dari nilai reliabilitas suatu variabel dan nilai Average Variance Extracted (AVE) dari masing-masing variabel. Variabel dikatakan memiliki reliabilitas yang tinggi jika nilai composite reliablity di atas 0,70 dan AVE berada di atas 0,50. Pada Tabel 3 akan disajikan nilai Composite Reliability.

Tabel 3. Nilai Composite Reliability

\begin{tabular}{cc}
\hline Variabel & Composite Reliability \\
\hline Green Marketing Mix $(\mathrm{X})$ & 0,921 \\
Value Perception $\left(\mathrm{Y}_{1}\right)$ & 0,840 \\
Minat Beli $\left(\mathrm{Y}_{2}\right)$ & 0,934 \\
\hline
\end{tabular}

Tabel 3 menginformasikan bahwa seluruh variabel memenuhi composite reliability karena nilainya di atas angka yang direkomendasikan, yaitu di atas 0,70 yang berarti bahwa seluruh variabel penelitian yang terdiri dari Green Marketing Mix, Value Perception, dan Minat Beli sudah memenuhi kriteria reliabel. Berdasarkan dari hasil evaluasi secara keseluruhan, baik convergent validity, discriminant validity, dan composite reliability sebagaimana telah dipaparkan di atas, maka dapat dinyatakan bahwa indikator-indikator sebagai pengukur variabel laten merupakan pengukur yang valid dan reliabel.

\section{HASIL DAN PEMBAHASAN}

\subsection{Analisis Data}

\subsubsection{Pengujian Model Struktural (Inner Model)}

Pengujian inner model atau model struktural dilakukan untuk melihat hubungan antara variabel, nilai signifikansi dan $R$-square dari model penelitian. Model struktural dievaluasi dengan menggunakan $R$-square untuk variabel dependen, uji $\mathrm{t}$ serta signifikansi dari koefisien parameter jalur struktural. Dari gambar model struktural dapat dijelaskan bahwa covariance pengukuran indikator dipengaruhi oleh konstruk laten atau mencerminkan variasi dari konstruk unidimensional yang digambarkan dengan bentuk lingkaran dengan beberapa anak panah dari konstruk ke indikator. Model ini menghipotesiskan bahwa perubahan pada konstruk laten mempengaruhi perubahan pada indikator. Dalam model 


\section{NATIONALLY ACCREDITED J OURNAL - DECREE NO, 21/E/KPT/2018}

tersebut terdapat satu variabel eksogen yaitu Green Marketing Mix, satu variabel endogen antara yaitu Value Perception, serta satu variabel endogen terikat yaitu Minat Beli.

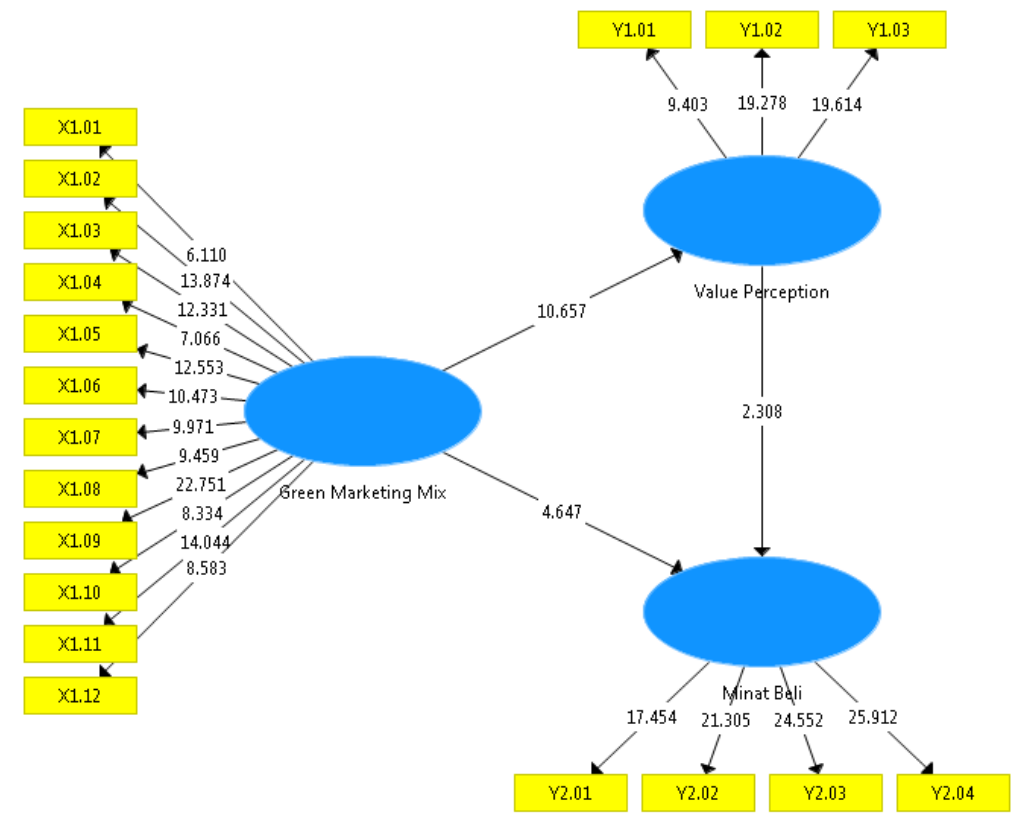

Penilaian model dengan PLS dimulai dengan melihat $R$-square untuk setiap variabel laten dependen. Perubahan nilai $R$-square dapat digunakan untuk menilai pengaruh variabel laten eksogen tertentu terhadap variabel laten endogen yang mempunyai pengaruh substantif. Tabel 4 memperlihatkan hasil estimasi $R$-square dengan menggunakan SmartPLS.

Tabel 4. Nilai R-Square

\begin{tabular}{cc}
\hline Variabel & R-Square \\
\hline Value Perception $\left(\mathrm{Y}_{1}\right)$ & 0,508 \\
Minat Beli $\left(\mathrm{Y}_{2}\right)$ & 0,588 \\
\hline
\end{tabular}

Tabel 4 menunjukkan nilai $R$-square variabel Value Perception 0,508 dan Minat Beli 0,588. Semakin tinggi nilai $R$-square, maka semakin besar kemampuan variabel eksogen tersebut dapat dijelaskan oleh variabel endogen sehingga semakin baik persamaan struktural yang dibangun dalam model penelitian. Untuk variabel Value Perception memiliki nilai $R$-square sebesar 0,508 (moderat) yang berarti 50,80 persen varian Green Marketing Mix mampu dijelaskan oleh variabel Value Perception sedangkan sisanya dijelaskan oleh variabel lain di luar model penelitian. Variabel Minat Beli memiliki nilai $R$-square 0,588 (moderat) yang berarti 58,80 persen varian Green Marketing Mix dan Value Perception mampu dijelaskan oleh variabel Minat Beli sedangkan sisanya dijelaskan oleh variabel lain di luar model penelitian.

\subsubsection{Pengujian Hipotesis Penelitian}

Signifikansi parameter yang diestimasi memberikan informasi yang sangat berguna mengenai hubungan antara variabel-variabel penelitian. Dasar yang digunakan dalam menguji hipotesis adalah nilai yang terdapat pada output result for inner weight. Tabel 5 memberikan output estimasi untuk pengujian model struktural. 


\section{NATIONALLY ACCREDITED J OURNAL - DECREE NO, 21/E/KPT/2018}

Tabel 5. Result For Inner Weights

\begin{tabular}{cccccc}
\hline Variabel & $\begin{array}{c}\text { Original } \\
\text { Sample }\end{array}$ & $\begin{array}{c}\text { Standard } \\
\text { Error }\end{array}$ & T Statistics & P Values & Kesimpulan \\
\hline $\begin{array}{c}\text { Green Marketing Mix }(\mathrm{X}) \\
\rightarrow \text { Value Perception }\left(\mathrm{Y}_{1}\right)\end{array}$ & 0,713 & 0,067 & 10,657 & 0,000 & Diterima \\
$\begin{array}{c}\text { Green Marketing Mix }(\mathrm{X}) \\
\rightarrow \text { Minat Beli }\left(\mathrm{Y}_{2}\right)\end{array}$ & 0,547 & 0,118 & 4,647 & 0,000 & Diterima \\
$\begin{array}{c}\text { Value Perception }\left(\mathrm{Y}_{1}\right) \\
\rightarrow \text { Minat Beli }\left(\mathrm{Y}_{2}\right)\end{array}$ & 0,274 & 0,119 & 2,308 & 0,021 & Diterima \\
\hline
\end{tabular}

Hipotesis 1 menyatakan bahwa Green Marketing Mix berpengaruh positif dan signifikan terhadap Value Perception. Hasil uji terhadap koefisien parameter antara Green Marketing Mix terhadap Value Perception menunjukkan adanya hubungan yang positif dengan nilai koefisien sebesar 0,713 dengan nilai t-statistik sebesar 10,657 dan signifikan pada $a=0,050$. Nilai t-statistik tersebut berada di atas nilai kritis 1,960, dengan demikian $\mathrm{H}_{\mathrm{a}}$ diterima yang berarti ada pengaruh signifikan dari Green Marketing Mix terhadap Value Perception pada pelanggan The Body Shop di Kota Mataram. Hal ini menyatakan bahwa salah satu penentu baik tidaknya Value Perception Pelanggan The Body Shop di Kota Mataram adalah Green Marketing Mix produk. Jika Green Marketing Mix tinggi maka Value Perception pada pelanggan The Body Shop di Kota Mataram akan tinggi, dan sebaliknya jika Green Marketing Mix rendah maka Value Perception pada pelanggan The Body Shop di Kota Mataram juga akan menjadi rendah pula.

Hipotesis 2 menyatakan bahwa Green Marketing Mix berpengaruh positif dan signifikan terhadap Minat Beli. Hasil uji terhadap koefisien parameter antara Green Marketing Mix terhadap Minat Beli menunjukkan adanya hubungan yang positif dengan nilai koefisien sebesar 0,547 dengan nilai t-statistik sebesar 4,647 dan signifikan pada $\alpha=0,050$. Nilai $t-$ statistik tersebut berada di atas nilai kritis 1,960, dengan demikian $\mathrm{H}_{\mathrm{a}}$ diterima yang berarti ada pengaruh yang signifikan dari Green Marketing Mix terhadap Minat Beli pelanggan The Body Shop di Kota Mataram. Tinggi rendahnya Minat Beli pelanggan The Body Shop di Kota Mataram dapat ditentukan oleh tinggi rendahnya Green Marketing Mix, semakin tingi Green Marketing Mix maka Minat Beli pelanggan The Body Shop di Kota Mataram akan semakin tinggi dan sebaliknya jika Green Marketing Mix rendah maka Minat Beli pelanggan The Body Shop di Kota Mataram juga akan rendah pula.

Hipotesis 3 menyatakan bahwa Value Perception berpengaruh positif dan signifikan terhadap Minat Beli. Hasil uji terhadap koefisien parameter antara Value Perception terhadap Minat Beli menunjukkan adanya hubungan yang positif dengan nilai koefisien sebesar 0,274 dengan nilai t-statistik sebesar 2,308 dan signifikan pada $a=0,050$. Nilai $t-$ statistik tersebut berada di atas nilai kritis 1,960, dengan demikian $\mathrm{H}_{\mathrm{a}}$ diterima dimana hasil pengujian tersebut membuktikan bahwa Value Perception berpengaruh positif dan signifikan terhadap Minat Beli pelanggan The Body Shop di Kota Mataram. Ini berarti peningkatan Value Perception akan memberikan dampak meningkatnya Minat Beli pelanggan The Body Shop di Kota Mataram, dan sebaliknya jika Value Perception yang dirasakan kurang/tidak baik, maka berdampak pada Minat Beli pelanggan The Body Shop di Kota Mataram yang menjadi semakin rendah.

Besarnya pengaruh tidak langsung variabel Green Marketing Mix terhadap Minat Beli melalui variabel Value Perception diperoleh dari hasil perkalian koefisien jalur (beta) antara pengaruh langsung Green Marketing Mix terhadap Value Perception dengan pengaruh langsung Value Perception terhadap Minat Beli pelanggan The Body Shop di Kota Mataram. Besarnya pengaruh Green Marketing Mix terhadap Minat Beli dengan mediasi variabel Value Perception yaitu sebesar 0,380 $(0,704 \times 0,539)$. Untuk melihat lebih jelas besarnya 


\section{NATIONALLY ACCREDITED J OURNAL - DECREE NO. 21/E/KPT/2018}

mediasi variabel/ pengaruh tidak langsung antara variabel bebas Green Marketing Mix terhadap Minat Beli dengan mediasi variabel Value Perception, dapat dilihat pada Tabel 6 berikut :

Tabel 6. Perhitungan Pengaruh Tidak Langsung

\begin{tabular}{ccc}
\hline Pengaruh Variabel & $\begin{array}{c}\text { Formula } \\
\text { Perhitungan }\end{array}$ & Hasil \\
\hline $\begin{array}{l}\text { Rangkuman Pengaruh Langsung (Direct Effect) } \\
\rightarrow \text { Value Perception }\left(\mathrm{Y}_{1}\right)\end{array}$ & 0,713 \\
$\quad$ Value Perception $\left(\mathrm{Y}_{1}\right)$ & - & 0,274 \\
$\rightarrow$ Minat Beli $\left(\mathrm{Y}_{2}\right)$ & - & \\
\hline & Rangkuman Pengaruh Tidak Langsung (Indirect Effect) \\
\hline $\begin{array}{l}\text { Green Marketing Mix }(\mathrm{X}) \\
\rightarrow \text { Value Perception }\left(\mathrm{Y}_{1}\right) \\
\rightarrow \text { Minat Beli }\left(\mathrm{Y}_{2}\right)\end{array}$ & 0,195 \\
\hline
\end{tabular}

Dengan demikian diketahui bahwa variabel Green Marketing Mix secara tidak langsung dapat mempengaruhi variabel Minat Beli pelanggan The Body Shop di Kota Mataram melalui perantara variabel Value Perception dengan nilai koefisien sebesar 0,195. Hasil ini menyatakan bahwa terdapat pengaruh tidak langsung yang signifikan dari Green Marketing Mix terhadap Minat Beli pelanggan The Body Shop di Kota Mataram melalui Value Perception.

Berdasarkan hasil analisis Partial Least Square dengan smartPLS didapatkan nilai koefisien dari Value Perception 0,274, lebih kecil dibanding Green Marketing Mix sebesar 0,713. Artinya bahwa 27,40 persen Minat Beli pelanggan The Body Shop di Kota Mataram dipengaruhi oleh Value Perception. Dari hasil penelitian ini bisa dinyatakan bahwa Green Marketing Mix lebih dominan dalam meningkatkan Minat Beli pelanggan jika dibandingkan dengan Value Perception. Hal ini menunjukkan bahwa variabel Value Perception memiliki pengaruh yang lebih rendah terhadap Minat Beli jika dibandingkan dengan variabel Green Marketing Mix.

\subsection{Pembahasan}

\subsubsection{Pengaruh Green Marketing Mix terhadap Value Perception}

Hasil penelitian menunjukkan Green Marketing Mix berpengaruh positif dan signifikan terhadap Value Perception. Temuan ini sesuai dengan pendapat Stevanie (2015) yang menyatakan terdapat pengaruh positif yang signifikan antara Green Marketing Mix dan Value Perception. Jika Green Marketing Mix diterapkan dengan baik pada suatu produk akan berdampak pada meningkatnya Value Perception terhadap produk yang ditawarkan. Senada dengan Dhewi et al, (2018) yang menjelaskan bahwa Green Marketing Mix berkaitan erat dengan Value Perception.

Temuan dalam penelitian ini juga menegaskan pendapat Pujari (2003), dimana Green Marketing Mix yang diukur melalui empat dimensi yaitu green product, green price, green place, dan green promotion dapat dengan signifikan meningkatkan Value Perception. Hal ini memberikan petunjuk bahwa hipotesis penelitian diterima. Green Marketing Mix yang diterapkan oleh The Body Shop berdampak positif dan signifikan terhadap Value Perception pelanggan di Kota Mataram. Cara Green Marketing Mix yang diterapkan dilihat dari manfaat langsung yang dirasakan oleh pelanggan berdampak positif dan signifikan terhadap Value Perception The Body Shop. Hal ini mengandung arti bahwa semakin tinggi dan meningkat Green Marketing Mix maka Value Perception pada pelanggan The Body Shop di Kota Mataram akan meningkat. 


\section{NATIONALLY ACCREDITED J OURNAL - DECREE NO, 21/E/KPT/2018}

Penelitian ini sejalan dengan penelitian yang dilakukan oleh Stevanie (2015) dan Dhewi et al, (2018). Berdasarkan penelitian ini dapat dijelaskan bahwa Green Marketing Mix memang sangat mempengaruhi tingkat Value Perception seorang pelanggan. Semakin tinggi Green Marketing Mix akan ikut meningkatkan tingginya Value Perception, meskipun menurut sifatnya Value Perception itu sendiri sangat relatif atau berbeda antara orang yang satu dengan orang lainnya. Hasil tersebut dapat dipahami karena sejalan dengan konsep bahwa Value Perception sebagai suatu keadaan dimana pelanggan The Body Shop di Kota Mataram selama menggunakan produk kosmetik tersebut merasa puas karena kebutuhan, keinginan, dan harapan pelanggan terhadap produk The Body Shop dapat terpenuhi.

\subsubsection{Pengaruh Green Marketing Mix terhadap Minat Beli}

Berdasarkan hasil analisis data menunjukkan bahwa terdapat pengaruh positif dan signifikan dari Green Marketing Mix terhadap Minat Beli. Hasil ini menyatakan bahwa pendapat yang dikemukakan oleh Kong et al, (2014) dimana Minat Beli salah satunya dipengaruhi oleh Green Marketing Mix. Senada dengan temuan dalam penelitian Yani \& Astuti (2016) dimana Green Marketing Mix dapat mempengaruhi Minat Beli menjadi meningkat.

Hasil penelitian ini dapat diartikan bahwa Green Marketing Mix yang diterapkan oleh The Body Shop sangat berpengaruh nyata terhadap Minat Beli pelanggan The Body Shop di Kota Mataram. Hasil analisis data menunjukan bahwa Green Marketing Mix berpengaruh positif dan signifikan terhadap Minat Beli pelanggan The Body Shop di Kota Mataram. Ini artinya Green Marketing Mix yang diukur melalui 12 item indikator berpengaruh positif dan signifikan terhadap Minat Beli pelanggan The Body Shop di Kota Mataram. Dengan demikian diketahui bahwa Green Marketing Mix yang telah diterapkan oleh The Body Shop, berdampak positif dan signifikan terhadap Minat Beli. Semakin baik penerapan Green Marketing Mix yang dilakukan oleh produsen terhadap produknya, maka semakin baik pula Minat Beli pada produknya.

Hasil penelitian ini juga didukung oleh penelitian terdahulu seperti yang dilakukan oleh Kong et al, (2014) serta Yani \& Astuti (2016), dimana Green Marketing Mix berpengaruh positif dan signifikan terhadap Minat Beli. Ini membuktikan bahwa Green Marketing Mix berpengaruh positif dan signifikan terhadap Minat Beli pelanggan The Body Shop di Kota Mataram. Berdasarkan penelitian ini dapat dijelaskan bahwa Green Marketing Mix memang sangat diperlukan oleh perusahaan untuk diterapkan ke dalam setiap produknya agar mencapai Minat Beli yang tinggi dan mencapai salah satu predikat yang telah ditentukan oleh organisasi lingkungan hidup.

\subsubsection{Pengaruh Value Perception terhadap Minat Beli}

Hasil analisis data menunjukkan bahwa Value Perception yang diukur melalui tiga indikator yaitu nilai fugsional, nilai emosional, dan nilai ekspresi diri, berpengaruh positif dan signifikan terhadap Minat Beli. Hal ini mengandung arti bahwa semakin meningkat Value Perception pada pelanggan The Body Shop di Kota Mataram maka pelanggan akan mengalami peningkatan Minat Beli. Begitu juga sebaliknya jika Value Perception terhadap produk rendah, maka Minat Beli pelanggan terhadap produk akan mengalami penurunan. Temuan dalam penelitian ini semakin mempertegas pendapat yang dikemukakan oleh Chan (1999) dan Ottman (1995) bahwa konsumen yang berwawasan lingkungan cenderung melakukan kepedulian lingkungan yang kuat, dan konsumen lebih memilih produkproduk yang ramah lingkungan dibandingkan produk yang lain. Selain itu juga mengkonfirmasi temuan Rosiana (2017) yang menyebutkan bahwa Value Perception dapat menyebabkan Minat Beli. Demikian halnya dengan temuan Cahyani \& Wardana (2017) 


\section{NATIONALLY ACCREDITED J OURNAL - DECREE NO, 21/E/KPT/2018}

mengenai pengaruh antara Value Perception dengan Minat Beli, dimana pelanggan yang memiliki Value Perception yang baik dapat meningkatkan Minat Beli, sehingga hipotesis dalam penelitian ini dapat dibuktikan.

Penelitian ini sejalan dengan penelitian yang telah dilakukan oleh Pratama (2014). Hasil penelitiannya menyatakan bahwa Value Perception berpengaruh positif terhadap Minat Beli pelanggan. Berdasarkan penelitian ini dapat dijelaskan bahwa Value Perception memang sangat signifikan dalam mempengaruhi tingkat Minat Beli seorang pelanggan, meskipun menurut sifatnya Value Perception itu sendiri sangat relatif atau berbeda antara satu orang dengan orang lainnya.

\subsubsection{Pengaruh Tidak Langsung Green Marketing Mix terhadap Minat Beli melalui Value Perception}

Penelitian ini menyatakan bahwa Minat Beli secara tidak langsung dipengaruhi oleh variabel Green Marketing Mix melalui variabel Value Perception, dimana kontribusi persentase nilai yang diberikan relatif besar. Temuan ini dapat mengkonfirmasi pendapat yang dikemukakan oleh Saraswaty \& Suprapti (2015), dimana Green Marketing Mix yang baik akan meningkatkan Value Perception pelanggan dan pada akhirnya akan berdampak terhadap peningkatan Minat Beli pelanggan yang menjadi semakin tinggi. Hasil penelitian juga didukung oleh penelitian Suprapto \& Efendi (2017) yang menyatakan Green Marketing Mix dapat meningkatkan Value Perception, dimana pelanggan yang memiliki persepsi yang baik adalah pelanggan dengan tingkat Minat Beli yang tinggi.

Hasil penelitian ini semakin menegaskan kerangka teori penelitian Aprilisya et al, (2017), dimana temuannya menyatakan bahwa adanya Green Marketing Mix yang baik akan menimbulkan Value Perception yang baik terhadap produk yang ditawarkan dan pada akhirnya akan meningkatkan Minat Beli pelanggan tersebut. Temuan ini memberikan pedoman bagi perusahaan kosmetik The Body Shop dalam mengelola Green Marketing Mix produknya. Green Marketing Mix dapat mempengaruhi Minat Beli pelanggan The Body Shop di Kota Mataram dengan mediasi Value Perception, ini berarti bahwa semakin tinggi Green Marketing Mix yang diaplikasikan dalam produk kosmetik The Body Shop maka semakin tinggi Value Perception yang pada akhirnya akan memperbaiki Minat Beli yang dimiliki pelanggan.

Berdasarkan hasil yang ditunjukan R-square menyatakan bahwa Minat Beli dipengaruhi oleh dua variabel Green Marketing Mix dan Value Perception. Kedua variabel bebas tersebut memberikan kontribusi persentase nilai relatif sedang (58,80 persen) karena disebabkan adanya faktor-faktor lain yang tidak digunakan dalam model penelitian. Temuan ini memberikan pedoman bagi perusahaan kosmetik The Body Shop dalam mengelola Minat Beli pelanggannya, agar semakin tinggi serta tetap dapat dipertahankan. Value Perception seorang pelanggan juga dipengaruhi oleh berbagai macam faktor yang juga akan mempengaruhi Minat Beli seseorang dalam menggunakan produk kosmetik The Body Shop.

\section{KESIMPULAN}

Green Marketing Mix berpengaruh positif dan signifikan terhadap Value Perception. Hal ini menunjukkan bahwa semakin baik Green Marketing Mix yang diterapkan oleh perusahaan The Body Shop, maka Value Perception pelanggan akan meningkat, begitu juga sebaliknya. Green Marketing Mix berpengaruh positif dan signifikan terhadap Minat Beli. Hal ini berarti bahwa semakin baik Green Marketing Mix produk kosmetik The Body Shop, maka Minat Beli pelanggan akan semakin tinggi, demikian sebaliknya. Value Perception berpengarurh 


\section{NATIONALLY ACCREDITED J OURNAL - DECREE NO. 21/E/KPT/2018}

positif dan signifikan terhadap Minat Beli. Hasil ini membuktikan bahwa semakin baik Value Perception pelanggan terhadap produk kosmetik The Body Shop, maka Minat Beli pelanggan The Body Shop di Kota Mataram akan semakin tinggi, begitu juga sebaliknya.

\section{SARAN}

Perusahaan yang mengangkat isu green marketing mix The Body Shop harus terus meningkatkan nilai positif Green Marketing Mix tentang lingkungan dimata konsumen, memberikan kualitas tambahan agar dapat meningkatkan Value Perception konsumen yang nantinya akan menimbulkan kepercayaan pada produk The Body Shop. The Body Shop sebaiknya lebih memberikan informasi yang detail dan akurat mengenai produk yang ditawarkan. Hal ini akan meningkatkan pengetahuaan konsumen terhadap produk khususnya mengenai green marketing dan produk ramah lingkungan, sehingga memudahkan konsumen dalam mengevaluasi produk untuk meningkatkan minat pembelian, terutama untuk konsumen yang mulai beralih menggunakan produk-produk yang aman terhadap kesehatan. Apalagi jika melihat persaingan produk kecantikan saat ini yang semakin ketat, serta semakin banyaknya produk-produk kecantikan yang menggunakan bahan yang ramah lingkungan agar dapat menarik minat konsumen akan produk tersebut.

The Body Shop benar-benar memenuhi janjinya dengan konsumen sebagai produk yang ramah lingkungan sehingga upaya yang dapat dilakukan dalam meningkatkan Value Perception adalah membuat hubungan yang kuat antara produsen produk kecantikan dengan konsumen melalui green event tentang pentingnya gaya hidup ramah lingkungan dan pentingnya menggunakan produk kecantikan ramah lingkungan, sehingga konsumen memiliki persepsi bahwa produk kecantikan The Body Shop benar-benar memenuhi janjinya dengan konsumen sebagai produk yang ramah lingkungan. Dengan menciptakan hubungan yang kuat dengan konsumen, maka tidak hanya meningkatkan Value Perception mereka terhadap produk kecantikan ramah lingkungan namun juga meningkatkan Minat Beli mereka terhadap produsen produk kecantikan ramah lingkungan. Salah satu cara paling efektif yang bisa dilakukan untuk meningkatkan Value Perception dan Minat Beli adalah dengan membuat subjek promosi yang lebih mendukung kepedualian lingkungan secara riil, misalnya pogram penyelamatan binatang langka, mengadakan kegiatan kebersihan sungai atau program penanaman pohon yang melibatkan pelanggan secara langsung.

\section{DAFTAR PUSTAKA}

Aaker, D.A., (1997) Should You Take Your Brand to Where the Action is?, Harvard Business Review, 75: 135-143.

Cahyani, N.L.T.H., \& Wardana, I.M., (2017) Peran Green Trust Dalam Memediasi Pengaruh Green Product Perception Terhadap Green Repurchase Intention, E-Jurnal Manajemen Unud, 6 (6): 2933-2966.

Chan, R.Y.K., (1999) Environmental Attitudes and Behaviour of Consumer in China, Journal of International Consumer Marketing, 11 (4): 25-52.

Chan, R.Y.K., Lorett, B., \& Lau, Y., (2001) Antecedents of Green Purchases: A Survey in China, Journal of Consumer Marketing, 17 (4): 338-357.

Dodds, W.B., Monroe, K.B., \& Grewal, D., (1991) Effect of Price, Brand and Store Information on Buyers Product Evaluation, Journal of Marketing Research, 28: 307-319.

Ferdinand, A., (2014) Metode Penelitian Manajemen, Semarang: Badan Penerbitan Universitas Diponegoro. 


\section{NATIONALLY ACCREDITED J OURNAL - DECREE NO. 21/E/KPT/2018}

Ghozali, I., \& Latan, H., (2015) Partial Least Squares: Konsep, Teknik dan Aplikasi Menggunakan Program SmartPLS 3.0 untuk Penelitian Empiris, Edisi 2, Semarang: Badan Penerbit Universitas Diponegoro.

Kong, W., Harun, A., Sulong, R.S., \& Lily, J., (2014) The Influence of Consumers Perception of Green Product on Green Purchasing Intention, International Journal of Asian Social Science, 4(8): 924-939.

Kotler, P., \& Keller, K.L., (2012) Principle of Marketing, Global Edition, 14th Edition, USA: Pearson Education Limited.

Manongko, A.A.C., (2011) Green Marketing dan Pengaruhnya Terhadap Keputusan Pembelian Melalui Minat Membeli Produk Organik (Studi pada Pelanggan Produk Organik di Kota Manado), e-Journal.

Ottman, J., (1995) Today's Consumers Turning Lean and Green, Marketing News, 29 (23): 1214.

Pratama, M.A., (2014) Pengaruh Green Perceived Value, Green Perceived Risk dan Green Trust Terhadap Green Purchase Intention Lampu Philips LED di Surabaya, Calyptra: Jurnal Ilmiah Mahasiswa Universitas Surabaya, 3 (1): 1-20.

Prothero, A., \& Fitchett, J.A., (2000) Greening Capitalism: Opportunities for a Green Commodity, Journal of Macromarketing, 20 (1).

Rehman, Z.U., \& Khyzer, M., (2013) Conceptualizing Green Purchasing Intention in Emerging Market: An Empirical Analysis on Pakistan, The 2013 WEI International Academic Conference Proceeding, Istanbul.

Retnawati, B.B. (2011). Peningkatan Nilai Merek-Merek Asli Indonesia dengan Green Branding. Dinamika Sosial Ekonomi, 7(1), 1-9.

Sekaran, U., (2006) Metodologi Penelitian Untuk Bisnis, Jakarta: Salemba Empat.

Stevanie, C., (2015) Pengaruh Green Marketing Terhadap Nilai yang Dipersepsikan Dalam Keputusan Pembelian pada Ades (Studi Kasus pada Mahasiswa/i Fakultas Komunikasi dan Bisnis Telkom University), e-Proceeding of Management, 2 (1): 612-619.

Yani, M., \& Astuti, M., (2016) Pengaruh Green Marketing, Lingkungan dan Kesehatan Terhadap Keputusan Pembelian Melalui Minat Membeli Produk Organik (Studi pada Hero Supermarket Sidoarjo), Prosiding Seminar Nasional Ekonomi dan Bisnis $\mathcal{E}$ Call For Paper FEB UMSIDA, 336-351. 